\title{
INTERMEDIALITY, INTERTEXTUALITY AND PARODY: RESONANCES OF JANE AUSTEN IN JOHN FOWLES'S THE FRENCH LIEUTENANT'S WOMAN
}

\author{
Genilda Azerêdo ${ }^{1 \times}$
}

${ }^{1}$ Universidade Federal da Paraíba, João Pessoa, PB, Brasil

\begin{abstract}
This essay aims at investigating the significance of Jane Austen in John Fowles's The French Lieutenant's Woman. References to Austen's Persuasion appear three times in Fowles's novel, and the resonances of this intertextual dialogue substantially affect the politics of characterization and space (mainly the Cobb) in The French Lieutenant's Woman. This discussion is theoretically based on the relationship between intertextuality, intermediality and parody, so as to consider the relevance of Persuasion (a pre-Victorian novel) in a work which has been generally considered by critics as a parody of values and tenets of Victorian society and literature. What relationships are produced, in terms of both poetics and politics, when we think about the Austen-Fowles association?

Keywords: intermediality; intertextuality; parody; Jane Austen; John Fowles.
\end{abstract}

\footnotetext{
"Professora Titular da Universidade Federal da Paraiba, com atuação no curso de Graduação em Letras e no Programa de PósGraduação em Letras. É Pesquisadora PQ2 do CNPq desde 2009. É autora, dentre outros, dos livros: Jane Austen on the screen: a study of irony in Emma (João Pessoa: Editora Universitária da UFPB, 2009); Para celebrar Jane Austen: diálogos entre cinema e literatura (Curitiba: Appris, 2013); Reencenando imagens e palavras: anotações sobre literatura e filmes (João Pessoa: Editora Universitária da UFPB, 2013) e Olhares sobre o cinema brasileiro (Campinas: Pontes, 2016). E-mail: genildaazeredo@yahoo. com.br e genilda@cchla.ufpb.br.ORCID: https://orcid.org/0000-0003-1267-059X.
} 
"We can sometimes recognize the looks of a century ago on a modern face; but never those of a century to come."

(Fowles, TFLW)

\section{Introductory Notes}

John Fowles's The French Lieutenant's Woman ${ }^{1}$ (2004), published in 1969, is a representative English novel in terms of postmodern poetics and politics. The novel is composed of 61 chapters and each chapter is introduced with epigraphs that vary from Jane Austen's Persuasion (published in 1818), extracts of poems and narratives by Victorian writers and poets (as, for instance, Thomas Hardy, Alfred Tennyson, Matthew Arnold, G. M. Young, A. H. Clough), to Darwin's The Origin of Species and three books by Marx: German Ideology, Economic and Political Manuscripts, and Communist Manifesto. Many other authors and texts inform the epigraphs. In his acknowledgments, Fowles even points out the relevance of specific texts in this vast dialogue, especially as they relate to the Victorian age.

Actually, the epigraphs are perhaps the first thing one notices while leafing through Fowles's book. The quantity is such - and the same authors appear more than once -, that the epigraphs endow the novel with a visual and referential density, not only serving to frame each chapter and somehow direct its reading (though often through irony and parody) but also helping to establish associations among the texts (belonging to different aesthetic and cultural traditions), the authors quoted and Fowles himself. According to William Stephenson, "The French Lieutenant's Woman's citations of its Victorian sources are re-enactments rather than references: they form part of an extended, and often self-contradictory, pattern of performances by the narrator" $(2007,63)$. The variety of intertexts also affects the kind of metafiction created, allowing both a parodic dialogue with literature and history, thus giving rise to what one may call historiographic metafiction. It is as if the epigraphs visually announced the narrative in terms of an eloquent surface, a spatial pattern. As such, one could view Fowles's novel as representative of a postmodern sensibility, briefly understood as encompassing "cultural forms that display certain characteristics such as reflexivity, irony, parody, and often a mixing of the conventions of popular and "high art"' (Natoli and Hutcheon 1993, vii).

The novel also possesses a general epigraph, taken from Marx's discussion on the Jewish question (1844), which says: "Every emancipation is a restoration of the human world and of human relationships to man himself" (qtd. in Fowles). As Tiphaine Samoyault $(2008,64)$ explains in her book on intertextuality, epigraphs indicate both a separation (and we would add, difference) and an articulation of texts, since the text quoting and containing the epigraph appropriates the qualities and renown of preceding texts and authors, thus initially producing an affiliation effect. Being intertextual strategies, epigraphs simultaneously inscribe the significance of previous texts and impinge on them resonances of the new context. Thus, Fowles's general epigraph for The French Lieutenant's Woman anticipates a dialogic articulation of the novel with issues related to emancipation, freedom and human relationships. 
The French Lieutenant's Woman has been widely studied and discussed since its publication in 1969. A rapid search on the web for articles on the novel indicates the variety of approaches it has raised, ranging from feminism, evolution theory and existentialism to metafiction, historical approaches and postmodernism. In her Narcissistic Narrative: The Metafictional Paradox (1980), Linda Hutcheon dedicates a chapter entitled "Freedom through Artifice: The French Lieutenant's Woman" to an investigation of the novel. Seymour Chatman's Coming to Terms: The Rhetoric of Narrative in Fiction and Film (1990) also brings a chapter on Fowles's novel and its film adaptation by Harold Pinter and Karel Reisz; the chapter is entitled "A New Kind of Film Adaptation: The French Lieutenant's Woman". These two books, though theoretical, employ Fowles's novel (and film adaptation) as corpus for analytical investigation, which shows how his novel is representative of narrative experimentation and innovation. William Stephenson's Fowles's The French Lieutenant's Woman offers a discussion of the novel that includes its contexts, critical reception, language, style and form, and its rendition on screen. A collection of essays edited by James Acheson (2013) informs on the different perspectives Fowles's novel has been investigated, ranging from feminism and historical fiction, to the writing process, metafiction, adaptation studies and postmodernism.

Considering the plethora of critical discussions on Fowles's novel, I somehow feel the need to justify the present investigation. As the title of this article already anticipates - "Intermediality, Intertextuality and Parody: Resonances of Jane Austen in John Fowles's The French Lieutenant's Woman" - I aim at analyzing the meanings and effects, both formally and politically speaking, of Jane Austen's presence in The French Lieutenant's Woman. It is true that the novel has already been studied from the perspective of metafiction (see references above), but apparently no due consideration has been given to the specificity of Austen's two epigraphs, taken from Persuasion (1990) - appearing in chapters five and ten. Besides these epigraphs, an intertextual reference to Austen's novel also appears in chapter two of TFLW, when Ernestina refers to Louisa's fall on the Cobb's steps. Actually, metafictional analyses of TFLW tend to consider the parody of Victorian literature upon which it is constructed - with Jane Austen supposedly included in that historical context. However, being a pre-Victorian author, this constitutes a misrepresentation of Austen. Having this in mind, the following questions have motivated my discussion: what is Jane Austen's significance in TFLW? What relationships are produced, in terms of both poetics and politics, when we think about the Austen-Fowles association? Or when we think about Fowles's women and Austen's women? How does Austen's Persuasion shed light on Fowles's TFLW? And how does Fowles's TFLW contribute to our rereading of Austen's novel?

Scholars researching on intermediality have pointed out the relationship between intertextuality and intermediality. Claus Clüver, for instance, states that one term inevitably entails the other: "among intertexts of any text (in any medium) there are always references (quotations and allusions) to aspects and texts in other media" $(2011,17)$. In a text entitled "Intermediality, 
Intertextuality and 'Remediation", Irina Rajewsky also argues that "there is a narrow relationship between intermedial and intertextual references" $(2012,27)$. She explains, for instance, that "many insights from the debate on intertextuality - for instance, as related to textual markers and different modes of referencing - might be useful for an examination of intermedial phenomena" (Rajewsky 27). ${ }^{2}$ This argument has become persuasive in the investigation here, since Fowles's intertextual references encompass not only literature and history, but also cultural artifacts from the visual arts, thus expanding the context to an intermedial textuality. For instance, an initial and significant hypothesis underlying the articulation of TFLW and Persuasion has to do with literary description and visual potentiality, or what Liliane Louvel (2012) elaborates as ekphrastic and pictorial qualities in narrative fiction. In Fowles's vast dialogue with the Victorian age, references to different artistic practices abound, among which, poetry, painting, architecture, and drawing.

In her "Introduction" to Handbook of Intermediality (2015), Gabriele Rippl emphasizes the relevance of studying literature's role and function "in a cultural field characterized not only by the competition and collaboration of different media, but also by media interfaces" (2). In Fowles's novel, intermediality is expressed through pictorial and ekphrastic phenomena, initially understood, according to James A. W. Heffernan, as "the verbal representation of visual representation" $(2015,38)$; still according to Heffernan, "ekphrasis is a kind of writing that turns pictures into storytelling words" (48). In his appraisal of ekphrasis, Clüver calls attention to certain traditional definitions of the term which restrict its meaning to verbal representations of visual texts (works of art, paintings), but excluding verbalizations of non-figurative painting and architectonic works (18). In this discussion, I will consider the insertion of the Cobb in TFLW as having both an intertextual and intermedial (architectural) significance.

The French Lieutenant's Woman parodically resonates Austen's Persuasion through a very specific geographical location - Lyme, on the south coast of England -, and the Cobb, a very famous architectural English construction, a kind of heritage monument. In using the Cobb to initially locate his characters and introduce their dramas, Fowles not only re-presents an already known English architectural work, but reactivates the way Jane Austen had done that before him. As such, Fowles's parody draws significantly on verbal and visual intertextuality - hence, intermedial relations -, their meanings and effects, since the description of the Cobb - inserted as an ekphrastic moment - enriches the narrative "by inviting an already extant image, which has its own historical and theoretical associations, into the fictional discourse" (Karastathi 2015, 95). Other issues derive from the coincidence of setting, such as the danger inherent to the Cobb, the characterization of women who fall, and the diverse effects of their acts. Considering these aspects, in the discussion that follows, Persuasion and TFLW will be considered in light of their intermedial, intertextual and parodic resonances. 


\section{Jane Austen's Persuasion in John Fowles's The French Lieutenant's} Woman

It is a truth universally acknowledged that Jane Austen constitutes not only a literary but a cultural icon. Her place in the Western literary tradition was widely recognized and established much before Harold Bloom's chapter about Persuasion appeared in The Western Canon. Writers have always expressed their admiration for Jane Austen - as, for instance, Virginia Woolf (1988), in two critical texts about Austen; and Vladimir Nabokov (1982) in a critical text about Mansfield Park. Writers have always returned to Jane Austen and constructed literature through articulations with her universe, as for instance, Fay Weldon in Letters to Alice on First Reading Jane Austen (1984), John Fowles in TFLW, and, more recently, Ian McEwan, through several of his novels, among which, Atonement (2001) and Sweet tooth (2012). ${ }^{3}$

A rapid computer search for Austen-related books will result in a great quantity of the so-called fictional sequels of Austen's narratives. As early as 1913, Sybil G. Brinton published Old Friends and New Fancies: An Imaginary Sequel to the Novels of Jane Austen. Since then, this kind of publication has only largely increased. The titles reveal an interest in Jane Austen in terms of authorship, readership and fandom - as, for instance, Bridget Jones: the Edge of Reason (2001), by Helen Fielding; The Jane Austen Book Club (2005), by Karen Joy Fowler; Becoming Jane Austen (2007), by Joe Spence; Jane Austen Made me Do It: Original Stories Inspired by Literature's Most Astute Observer of the Human Heart (2011), edited by Laurel Ann Nattress, and written by different authors; Confessions of a Jane Austen Addict (2007), by Laurie Viera Rigler; more specifically, in writing stories from the perspective of certain characters - as, for instance, Jane Fairfax (1990), by Joan Aiken; The New Illustrated Darcy's Story (1999), by Janet Aylmer; Me and Mr. Darcy (2007), by Alexandra Potter; Mr. Darcy Broke My Heart (2010), by Beth Pattillo; The Secret Diary of Lizzie Bennet (2014), by Bernie Sue and Kate Rorick; or by giving emphasis to iconic settings in Austen's narratives, as for instance, P. D. James' Death comes to Pemberley (2011) and Joe Baker's Longbourn (2013).

It is also relevant to remark that several of these books - in addition to the (re)adaptations of all the Austen novels throughout time ${ }^{4}$ - were rendered on screen, as, for instance, Bridget Jones's Diary (dir. Sharon Maguire, 2001), The Jane Austen Book Club (dir. Robin Swicord, 2007) and Becoming Jane (dir. Julian Jarrold, 2007). In 2013, bicentenary anniversary of the publication of Pride and Prejudice (1813), The Lizzie Bennet Diaries was launched as a web series, directed by Bernie Sue and Margaret Dunlap, in the format of a vlog. ${ }^{5}$ The success was such that the series won an Emmy for Outstanding Creative Achievement in interactive media. In Brazil, in 2018, a local TV channel showed a soap opera entitled Orgulho e Paixão (Pride and Passion), written by Marcos Bernstein, with a free inspiration in the Austen novels.

Given the profusion and ubiquity of Austen's visibility throughout literary tradition and in contemporary times, it is worth investigating the effects of her 
presence in so many different contexts and materializations. What power inhabits Jane Austen as author(ity) that makes her be recurrently quoted, appropriated, ironized, and parodied? According to Foucault, in The Order of Discourse (1996), the circulation of discourses is controlled by mechanisms of interdiction and exclusion, which proves that not every text or narrative gets repeated. What potential keeps her novels alive, thus transforming her into a global and intermedia author? Still according to Foucault, the repetition - or the activation - of certain narratives, whose patterns vary in different contexts, responds to a basic prerogative - the belief that "there exists in them a secret or an asset" (22). Differently from pragmatic discourses, that tend to disappear as soon as they are uttered, Foucault calls attention to discourses that, though said, continue with an existence or a potentiality for being said again, referred to and quoted (22). Among such discourses, literary discourses certainly play a relevant role, since their polysemous nature allows different interpretations and re-enactments in various artistic expressions and media.

One should reflect further, along with Foucault, on the power that certain discourses have not only to produce but to make other discourses proliferate: "novelty lies not in what is said, but in the occurrence of its return" (26). That is, for Foucault, it is not enough to discuss the intertext, but to pursue what lies behind its new occurrence. If it is true that literary discourses are inexhaustible, it is even more true that Austen's literary discourses keep resonating among different readers and interpreters, in different times and cultures. The occurrence of such a return seems to be imbricated with the writer's authority, another discourse to be deciphered - after all, the author also constitutes "a sign(ifying) with multiple meanings" (Wiltshire 2001, 1). Why, then, do texts (novels, literary sequels, films, plays, web series, soap operas) always make one return to Jane Austen? Why does Jane Austen keep attracting other authors and other interpreters? What novelty lies in this eternal Austen return? I hope the discussion that follows, about the activation of Austen's Persuasion in TFLW, may contribute to an understanding of these questions. For one thing, some of Fowles's literary concerns could also be attributed to Jane Austen: man's relationship to nature; class and social hierarchy; sexuality; gender roles; authorship; the creative process; and the power of mystery (Stephenson 7).

The first chapter of TFLW introduces the main characters as situated in 1867, in Lyme Regis (a town on the southern coast of England), specifically Lyme Bay and the Cobb, the harbor wall, a singular architectural English construction. Descriptions of the place call attention to "the most disagreeable wind in Lyme Bay" (Fowles 3) and to the maritime architecture of the Cobb - "quite simply the most beautiful sea-rampart on the south coast of England" (Fowles 3). The narrator also refers to "the sombre grey cliffs, known locally as Ware Cleeves", and to the fact that the cliffs are "masked by dense woods" (Fowles 4). The characters are presented from a distance, both physically speaking - as if through a telescope -, and through vague references, such as "the pair", "two strangers", "the young lady", "the taller man", "the figure", "the other figure" (Fowles 4-5). Actually, the 
narrator adopts a position that initially ranges from a panoramic point of view (the town, the bay, the Cobb, the cliffs, the woods) to that of a discriminating, microscopic eye; other references to this visual semantic field are "focusing his telescope more closely", "the eye in the telescope" and "telescopist" (Fowles 4-5). The visual references not only introduce a curiosity about these characters, a desire to know who they are, but further align with the behavior of a spy and consequently with the issue of minding other people's lives and gossiping about them - can we help articulating with gossiping microcosms in Jane Austen? This chapter opens with an epigraph by Thomas Hardy - actually, the first stanza from his poem "The riddle", which says:

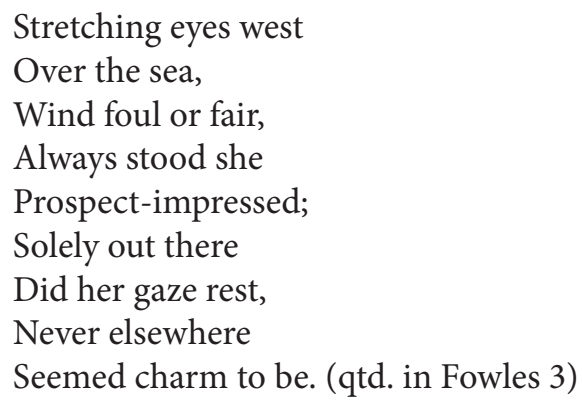

The epigraph - describing the state of a woman in the mode of a picture or a painting - clearly articulates with "the other figure" whose clothes were black and with whom the chapter ends: "The wind moved them [the clothes], but the figure stood motionless, staring, staring out to sea, more like a living memorial to the drowned, a figure from myth, than any proper fragment of the petty provincial day" (Fowles 5). In both extracts we have the presence of the sea, the wind, and of a woman (in Hardy) and a figure (in Fowles) standing motionless and staring, gazing at the sea. Interestingly, the intertextual parallelism with Hardy's epigraph somehow announces the figure to be a woman. More than this, the articulation between Hardy's character (a she) and Fowles's character (a figure) - created intertextually and visually - gets enlarged through the idea of a "riddle" (see title of the poem), "a figure from myth" to be deciphered. It is as if Fowles, by creating his figure, had promised an actualization, a materialization of Hardy's woman (who is actually a riddle, an enigma, a puzzle), by giving her - at least apparently - a more tangible and concrete existence. But the fact is that the figure helps to increase the riddle and the game, which get enhanced through other metafictional techniques as the narrative develops. It would not be an exaggeration to say that the extract from Hardy's poem is a significant ekphrasis for the way Fowles's character gets described and announced - both are characterized by what Karastathi calls "the freeze-time effect" (95). Interestingly, in "Notes on an Unfinished Novel" (1969), Fowles reveals that TFLW began with a visual image: "A woman stands at the end of a deserted quay and stares out to sea..." (qtd. in Bedggood 2013, 53).

Readers who are familiarized with Austen's Persuasion will immediately remember this novel while reading the opening chapter of TFLW, for Lyme Regis and the Cobb constitute relevant settings in Austen's novel. This shows 
a remarkable case of intertextuality as memory - the memory literature has of itself (Samoyault 10) - derived and produced by the artistic and cultural memory of authors, readers and interpreters. At first, the association might be raised on visual terms, an effect resulting from the narrator's descriptive ability:

... the Cobb itself, its old wonders and new improvements, with the very beautiful line of cliffs stretching out to the east of the town, are what the stranger's eye will seek; and a very strange stranger it must be, who does not see charms in the immediate environs of Lyme, to make him wish to know it better (Austen 93).

Besides the visual appeal offered by the novel, the Cobb is made more vivid because of the memory one has of its visual renderings on the covers of the novel's different editions, as well as on screen, both in the adaptations of Persuasion and $T F L W$. It is interesting to remark that both narrators (in Fowles and in Austen) not only describe the place, but situate it from the perspective of onlookers: a voyeur - a local spy in the first - and a stranger in the second. This strategy helps to increase the visual effect, as if inviting the reader to share in the act of looking. Besides, we have a chain of looking acts in TFLW: the narrator imagining a telescopist watching a figure watching, gazing at the sea...

In terms of intertextual verbal strategies, the significance gets enlarged: in Austen, the stranger's eye sees the beauties and charms of the Cobb and around Lyme; in Fowles, because the observer is characterized as a spy, a voyeur, he observes the strangers through a telescope, hence from a distance. The example shows a gap between Austen and Fowles, a gap I will analyze further when I consider the other intertextual articulations in TFLW. For the time being, it is enough to anticipate that Fowles appropriates Jane Austen, thus re-activating her significance, to say something different. It is exactly this difference that announces the parodic stance, and that gives rise to "an entirely new and particular relation between an author's truth and another's" (Bakhtin, qtd. in Samoyault 19).

In Chapter II of TFLW, the allusive articulation with Austen's Persuasion through the Cobb becomes textually tangible by means of a dialogue between the now named characters, Charles and Ernestina:

'These are the very steps that Jane Austen made Louisa Musgrove fall down in Persuasion.'

'How romantic.'

'Gentlemen were romantic...then.'

'And are scientific now? Shall we make the perilous descent?' (Fowles 8)

Even before the characters voice the association, this is exactly the scene that readers of Persuasion remember while reading the first chapter of TFLW. The enduring visual power of Austen's micro-narrative - Louisa's fall and its dramatic effects -- situated on the Cobb's steps, is attested, for instance, by Tennyson's famous wish while visiting Lyme: "show me the exact spot where Louisa Musgrove fell" ("The locations of Persuasion"). 
The dialogue also suggests a gap between Austen's time (romantic), the narrative diegetic time, 1867 (Victorian, scientific), and the contemporary time of the narrator (1969, postmodern sensibility). Charles's invitation, "Shall we make the perilous descent?"', clearly uttered in a humorously ironic way, gets enlarged when we think about an isotopy ${ }^{6}$ of fall and descent in TFLW. For it is exactly sometime after the reference to Louisa's fall in Austen, that Ernestina tells Charles the story behind the "black figure", the "dark shape", "poor Tragedy", "the French Lieutenant's...Woman" (Fowles 9) - in other words, the story about a fallen woman, morally speaking. This adds another significant dimension to the gap between Austen and Fowles: in the first, the danger inherent to the Cobb and the steps is situated on a physical level: Louisa's fall, though also provoked significant changes in terms of narrative development (mainly when one considers Anne and Wentworth's affective relationship in Persuasion), is literal, whereas the latter is metaphorical, because perceived on moral terms. Let us notice that by this time the character is not even named, being mainly defined in her (supposed and sinful) relation with the French lieutenant.

\section{Parody as Memory and Alterity: Of Different Falls and Gazes}

In her discussion of parody, Hutcheon calls attention to how parody affects the politics of representation; being an intertextual (and, one would add, interartistic and intermedial) strategy, parody appropriates past or previous aesthetic conventions in order to subvert them and distance from them. Hutcheon explains: "(...) through a double process of installing and ironizing, parody signals how present representations come from past ones and what ideological consequences derive from both continuity and difference" (The Politics of Postmodernism 1990, 93).

The double process of appropriating and incorporating in order to subvert provokes several effects. For Patricia Waugh, whose discussion is inserted in the context of literature, parody can be "regarded as [a] lever of positive literary change, for, by undermining an earlier set of fictional conventions which have become automatized, the parodist clears a path for a new, more perceptible set" (1984, 64). In this way, parody is viewed as a productive and creative strategy, instead of a parasitic or merely derivative resource, as traditional critics believed (Hutcheon, A Theory of Parody 2000, 3); another consequence is what Waugh names the educational potentiality of parody: “... the reader is educated in the relationship of historical and cultural to literary systems" (66). She explains: "Parody of a literary norm modifies the relation between literary convention and cultural-historical norms, causing a shift in the whole system of relations" (Waugh 66).

For Waugh, the shift provokes a de-familiarizing effect, resulting from a deviation of expected norms. But how does that affect the politics of representation? Why does an author make use of parody? How can one learn and critically position oneself about artistic tradition - in terms of formal conventions and politics of representation - through parodied works? For one thing, though 
occurring within (inter)textuality, "parody never claims to represent a full presence; like deconstruction, it is always a play of language before it is a play of meaning" (Phiddian 1997, 684). The reader must then become aware that, as a play, parody both repeats and hides, repeats and critically marks a difference, exactly because of the deconstructive subversion.

As Samoyault also states, "the appropriation of previous languages and genres produces effects of over-codification - that is, parodic texts themselves rely on codified forms" (22). In other words, the double-coded politics of parody (to use Hutcheon's expression) - materialized in terms of appropriation, and at the same time, subversion of forms and conventions - must be understood in terms of production and reception, i. e., both in relation to authors and artists who create parodic works, and readers and spectators who interpret them. Therefore, discussing parody is a challenging way of dealing with how aesthetic tradition produces innovation and experimentation - not only in terms of codes and formal conventions, but also in terms of social values, moral beliefs, and ideological perspectives. According to Hutcheon, "[i]rony makes these intertextual references into something more than simply academic play or some infinite regress into textuality: what is called to our attention is the entire representational process" (The politics of postmodernism 95).

To give an example, chapter five of TFLW brings as one of its epigraphs, another passage from Austen's Persuasion: "The young people were all wild to see Lyme" (qtd. in Fowles 26). In Austen, this statement by the narrator appears in chapter eleven, when Captain Wentworth received a letter from his friend Captain Harville, living in Lyme, and decided to go there for a visit, taking with him a party formed by Charles, Mary, Anne, Henrietta and Louisa. In Austen, we believe the narrator in telling us about the group's 'wildness' to see Lyme, since the trip is actually permeated by an atmosphere of novelty, excitement and joy. The event finds a parallelism in experiences lived by other Austen characters, as for instance, Catherine and her trip to Bath, in Northanger Abbey, also an opportunity for entertainment, knowing people and sharing relationships. However, coming across this passage in Fowles's TFLW, one already suspects a subversion of meaning, which gets to be materialized when one reads the chapter:

An indispensable part of her quite unnecessary regimen was thus her annual stay with her mother's sister in Lyme. Usually, she came to recover from the season; this year she was sent early to gather strength for the marriage. No doubt the Channel breezes did her some good, but she always descended in the carriage to Lyme with the gloom of a prisoner arriving in Siberia. The society of the place was as up-to-date as Aunt Tranter's lumbering mahogany furniture; and as for the entertainment, to a young lady familiar with the best that London can offer it was worse than nil. (Fowles 28-9)

The 'young lady' in the passage is Ernestina, Charles's fiancée. The words 'regimen', 'gloom' and 'prisoner' express a very heavy atmosphere; besides, the 
comparison of Lyme's society up-datedness with Aunt Tranter's 'lumbering mahogany furniture' not only indicates the narrator's ironical perspective, but, in doing so, demarcates the gap with Austen's characters, in their lightness, excitement and affective warmth. The whole chapter is an introduction to Ernestina's character, both physically and emotionally speaking, depicted in a self-conscious and prudish Victorian way. Fowles's parodic dialogue with Austen and also with Victorian conventions - and his explicit invitation for the reader to share them - transcends the literary context so as to include the visual tradition as well: "Ernestina had exactly the right face for her age; that is, smallchinned, oval, delicate as a violet. You may see it still in the drawings of the great illustrators of the time - in Phiz's work, in John Leech's" (Fowles 26). In other words, the narrator's authority finds support in other registers, in this case, visual ones, which the reader might easily consult and verify.

But perhaps the most significant parody in TFLW, as it relates to Austen's Persuasion, has to do with Sarah's different slips and falls - on physical and moral terms. Actually, these different falls (as anticipated in the previous part of this discussion) initially find an ironic articulation with Louisa's fall on the Cobb's steps. Another relevant setting for the generation of irony and parody is the environment around the Bay, referred to as the Undercliff and Ware Commons, where Charles and Sarah frequently meet and develop an intimate relationship. Again, Fowles incorporates Austen's passage - this time, another epigraph in chapter ten of TFLW - in order to re-present (in both senses, present again and depict) the wild countryside, as being now characterized and inhabited by supposedly sinful relationships.

The passage Fowles extracts from Austen is the following:

... with its green chasms between romantic rocks, where the scattered forest trees and orchards of luxuriant growth declare that many a generation must have passed away since the first partial falling of the cliff prepared the ground for such a state, where a scene so wonderful and so lovely is exhibited, as may more than equal any of the resembling scenes of the far-famed Isle of Wight .... (Fowles 66)

Austen's readers know the relevance of the countryside and of countryside life to her novels. In Pride and Prejudice, for instance, the description of Pemberley, Darcy's property, is composed in a way so as to provide Elizabeth (and the reader) with relevant information about the owner's personality and subjectivity. In Sense and Sensibility, different rural settings are contrasted so as to make the reader understand the kind of property the Dashwoods can afford, after the patriarch's death. In Mansfield Park, Antigua, a setting which hardly appears, or appears in a covert way, merely referred to, becomes emblematic of Austen's criticism of slavery in the sugar-cane plantation fields. ${ }^{7}$ Critics have also pointed out how Austen's novels simultaneously inscribe and critique images of Englishness. ${ }^{8}$ Here, in Persuasion, the description of natural setting emphasizes beauty, exuberance and the issue of time, so as to suggest that generations pass away, but nature lasts. 
The description also reflects the concept of the Romantic sublime by showing the grandiosity and everlasting attribute of nature.

In appropriating Austen's passage for using it as epigraph of chapter ten, a chapter introducing Charles's sexual attraction for Sarah, Fowles provokes a displacement that shows the different meanings of the same setting for both authors. In Austen, this natural setting is presented as a mass, in a panoramic way, as if untouched by people, primitive-like. In Fowles, the place is tinged with prohibited and sinful connotations:

'But what is the sin in walking on Ware Commons?'

'The sin! You, a young woman, alone, in such a place!'

'But ma'm, it is nothing but a large wood.'

'I know very well what it is. And what goes on there. And the sort of person who frequents it'. (Fowles 91)

As the dialogue between Sarah and Mrs. Poulteney shows, in TFLW natural setting is articulated with outcast people, as represented further in the narrative by a gang of gypsies and Sarah herself, who frequently goes there, and where she secretly meets Charles. Being a scientist and paleontologist, Charles has the permission and legitimacy to go to the place, collect samples and carry out research. As to Sarah, "[Charles] could not imagine what, besides despair, could drive her, in an age where women were semi-static, timid, incapable of sustained physical effort, to this wild place" (Fowles 71). In Mrs. Poulteney's eyes, Ware Commons evokes Sodom and Gomorrah (Fowles 89), but differently from Mrs. Poulteney's "Bosch-like picture of Ware Commons" (Fowles 92), Sarah views it as a place where she can be left alone, where she can find peace. Let us notice how the narrator's visual references (this time guided by Mrs. Poulteney's biased perceptions) enhance an atmosphere of evil and sin. By describing Ware Commons in a metonymic way, by means of Hyeronimous Bosch', a fifteenth and sixteenth Dutch painter, whose work evokes sin and moral failings, the narrator contaminates the English setting with the iconography of his paintings and their ideological and critical perspectives.

It would be impossible to interpret Sarah's different slips and falls in TFLW without considering the general metafictional pattern of the novel. In fact, although belonging to the Victorian era, Sarah does not reflect the attributes associated with the age, as seen through Charles above. In other words, Sarah is not semi-static, timid, or incapable of sustained physical effort. Because she embodies a subjectivity characterized by freedom, sensuality and mystery, Charles feels completely attracted to her, whom he perceives through fragments of visual images and as symbol: “. . . that face, that mouth, that generous mouth. ... it was not Sarah in herself who attracted him - how could she, he was betrothed - but some emotion, some possibility she symbolized" (Fowles 130). The game Sarah plays triggers Charles to envision a different reality, away from the monotony and sameness of his life; at the same time, he feels pleased to act as her savior, as when she slips in the woods: ". . . she slipped on a treacherous angle of the muddied 
path and fell to her knees. He sprang forward and helped her up; now she was totally like a wild animal, unable to look at him, trembling, dumb" (Fowles 118). The narrator - who is also dramatized as a novelist - constructs Sarah in a mysterious and ambiguous way exactly to generate ironical discrepancy between what she seems to be (mainly when one considers the expectations and values of Victorian Lymers) and what she actually is. For that matter, a representative part of the novel is the end of chapter twelve and the beginning of chapter thirteen:

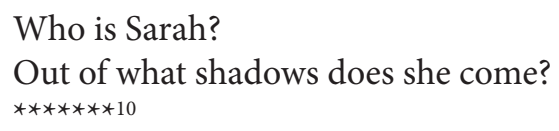

I do not know. This story I am telling is all imagination. These characters I create never existed outside my own mind. (Fowles 94-95)

We all know that fictional stories are all imagination and that characters do not exist outside narrators' minds. But we are only reminded of that in metafictional works, exactly because their purpose is to break away with the illusion of verisimilitude, by calling attention to the artifice and construction of aesthetic texts. As Patricia Waugh says, "the lowest common denominator of metafiction is simultaneously to create a fiction and to make a statement about the creation of that fiction" (6). As such, although chapter thirteen is the most explicitly metafictional, metafiction exists from the very beginning, not only through the narrator's contemporar $y^{11}$ ironical stance - and the strategy of viewing the characters through a telescope, in chapter one, enhances that distance -, but also because of the eloquent presence of different textualities (poems, passages from essays, explanatory footnotes, newspaper extracts and innumerous artistic allusions) which remind the reader that "the 'language of fiction' is always ... selfconscious" (Waugh 5), thus revealing the mediality of literature itself.

The juxtaposition and conflation of different texts and discourses in TFLW finds a parallelism in the different 'stories' the novel tells. In his discussion of Fowles's novel, Stephenson argues that

[t]o read The French lieutenant's woman is to follow the basic romance plot of the meeting, separation and reunion of Charles and Sarah. It is also to take a long, circuitous journey through Victorian literature, evolutionary science, Marxism, psychoanalysis, poststructuralist literary theory and the discourses of fashion, sexuality and the law. (33)

Actually, the basic romantic plot is appropriated in order to be subverted and parodied. All the other discourses relating to science, medicine, religion, sexuality, labor, artistic tradition and Victorian values serve the function to dismantle and disrupt the basic conventional plot of lovers. And a crucial strategy for this disruption is the very story of Sarah's attachment to the lieutenant - actually, her deliberate invention is so significant that it is used to entitle the novel. The reader first has access to Sarah's characterization through Ernestina's oblique and unspoken words, while they observe 'poor Tragedy' on the Cobb. Later on, 
Sarah's story is narrated to Mrs. Poulteney by the vicar. One gets to know that Sarah has worked as a governess, speaks French and suffers from grave attacks of melancholia; "[f]or that reason she may be frequently seen haunting the sea approaches to our town" (Fowles 35). It is only in chapters twenty and twentyone that we hear - along with Charles - Sarah's story narrated by Sarah herself; this comes at a time when her personality and character have somehow been established by second-hand gossiping discourses. By the way, early in chapter twelve, the dairyman has contradicted Charles, by saying, "And she been't no lady. She be the French Loot'n'nt's Hoer"' (Fowles 86). In chapter twenty, Sarah also names herself a whore:

What has kept me alive is my shame, my knowing that I am truly not like other women. I shall never have children, a husband, and those innocent happinesses they have. (...) I think I have a freedom they cannot understand. No insult, no blame, can touch me. Because I have set myself beyond the pale. I am nothing, I am hardly human any more. I am the French Lieutenant's Whore. (Fowles 176)

Besides the visual references mentioned above, Sarah's characterization on moral terms is enhanced throughout the narrative by literary references, such as "the scarlet woman of Lyme" (intertextual reference to Nathaniel Hawthorne's The scarlet letter) and Madame Bovary (Fowles 120, 122), nineteenth-century novels having female characters as fallen, outcast women.

But the fact is that Sarah is not a whore; as such, she is not the French lieutenant's woman either. Sarah has invented and embodied the character of the 'fallen woman' in order to live a life of her own, so as to have freedom and go wherever she wants. In this respect, she deliberately plots to have sexual intercourse with Charles, who only discovers she was a virgin after the act. Chapters twelve and thirteen are also relevant in their parody of females who fall. In chapter twelve, we have a scene in which Sarah was crying and "was standing at her window (...) as a preliminary to jumping from it" (Fowles 93). The scene is emblematic of Victorian fallen women, desperate and helpless, flirting suicide. However, because Sarah is a meta-character, the narrator is careful to laugh at this scene in the subsequent chapter:

I report, then, only the outward facts: that Sarah cried in the darkness, but did not kill herself; that she continued, in spite of the express prohibition, to haunt Ware Commons. In a way, therefore, she had indeed jumped; and was living in a kind of long fall, since sooner or later the news must inevitably come to Mrs. Poulteney of the sinner's compounding of her sin. (Fowles 98)

Let us emphasize the narrator's deliberate decision to manipulate Sarah, her acts, and emotions. Interestingly, because Sarah acts like a sinner, the Lymers around her are stirred in their most Victorian behavior of prejudice and meanness. But the most substantial effect is on Charles, early attracted, as 
we said above, by Sarah's mystery, her piercing eyes, her sensuality, her danger. The stanza from Hardy's "The riddle", opening chapter one and the novel, is a powerful introduction to Sarah's enigmatic nature. And Sarah's invented story and consequent dramatized character contributes to awaken in Charles a thoroughly new understanding of freedom, social values, and life.

Chapter forty-six, when Charles and Sarah meet at the hotel in Exeter and where they finally have sexual intercourse, is also permeated by a fall:

'Oh the poor young lady, sir, she was a-coming downstairs the day before yesterday morning and she slipped, sir. She's turned her ankle something horrible. Swole up big as a marrow ...'

He followed the plump maid's back to the top floor and was shown the scene of the accident. The stairs were certainly steep; and in those days, when they could rarely see their own feet, women were always falling; it was a commonplace of domestic life. (Fowles 346-347)

These examples demonstrate the substance and richness of the isotopy of 'fall' in TFLW. As in the case of Sarah's slip in the woods, here her fall also contributes to enrich her helplessness, thus making her more attractive to Charles, in his desire to protect and at the same time sexually possess her. Furthermore, the narrator takes advantage of the accident to denounce and criticize the way women dressed in Victorian times - with clothes that prevented them from seeing their own feet, thus making them vulnerable to falling and getting hurt.

Ironically, Sarah only gets to be an actual fallen woman (considering the Victorian moral perspectives) after having sex with Charles. Up to that point, the fallen Sarah had only been a story, a fantasy and fictional creation. It is Charles, rather than the lieutenant, the one responsible for her real 'fall'. Charles' discovery that he has been cheated gives rise to further enigmatic levels of Sarah's characterization. The questions the narrator asks at the end of chapter twelve could be uttered and re-enacted by Charles at this point: Who is Sarah? Out of what shadows does she come? As a character, Sarah is multi-coded and densely subjective, thus also illustrating the very multiple levels of the narrative.

The range of parody in TFLW is a very extensive one. As our scope here was limited to Austen's presence in Fowles's novel, we hope the examples elected are representative of the Austen-Fowles articulation. As such, Fowles's parody starts with a setting, a place - Lyme Regis, the Cobb - that evokes Austen and her Persuasion. Here, from the reader's perspective, parody results from a feeling of recognition derived from memory - both verbally and visually speaking. Gradually, the characters themselves voice the intertextual reference, in a gesture that enlarges the parodic ethos, so as to suggest a larger significant effect of the reunion of both authors. The epigraphs further determine the parodic articulation. By parodically referring to Louisa's fall, Fowles simultaneously gets near Jane Austen and moves away from her, thus revealing that parody is a strategy of otherness, of alterity. Fowles invites the reader to think again about Louisa's fall in Austen, but now guided by other contexts, other gazes and politics. 


\section{Concluding Remarks}

A general premise for the development of this investigation was the lack of critical discussion about the relevance of Jane Austen's Persuasion in Fowles's TFLW. When discussing Fowles's novel, critics generally refer to the parody of Victorian literature and values, without specifying the different historical and literary contexts informing Austen's authorship and the role it plays in TFLW. As this analysis shows, Austen is a key figure in the parodic politics of Fowles's novel.

For one thing, Fowles not only obliquely alludes to Jane Austen (chapter one), but explicitly refers to her, both in the narrative (chapter two) and in the epigraphs (chapters five and ten). The references might be seen as constituting a significant isotopy of fall, of the fallen woman, which gets amplified as the narrative develops, and becomes crucial for an understanding of Victorian female characterization and consequently of the modern woman Sarah in fact represents.

It is of paramount importance to remark that Fowles selects a micronarrative from Persuasion, the one dealing with Louisa's fall, and transforms it, by enlarging it and giving it a centrality that irradiates - on the level of Sarah's characterization, on the level of setting, and on the level of the multiple stories informing the narrative. Lyme Regis and the Cobb evoke Jane Austen and Louisa's fall, but simultaneously displace them, so as to bring to the foreground the drama of Victorian fallen women.

The intertextual dialogue with Austen is a relevant part of the visual appeal of $T F L W$. If in Austen the sea and the Cobb evoke the possibility of a re-engagement between Anne and Wentworth - ironically mediated by Louisa's fall on the Cobb's steps -, in Fowles the sea and the Cobb initially serve as significant backdrop for Sarah's drama as a fallen woman, staring out at the sea, supposedly waiting for her man. It is as if the setting in Fowles - because of the parodic displacement of the fall - were contaminated by an atmosphere of longing, regret, despair and tragedy. Also, it is as if there were an interchange of sensibility between setting - constructed as ekphrasis - and character. Both the Cobb - in its monumental architecture - and Sarah are there to be seen, to be appreciated.

The powerful visual potentiality of the Cobb is also enhanced by the mediation of Hardy's woman, as represented in his poem "The riddle", whose first stanza, appearing as epigraph of chapter one, already opens the novel and somehow introduces the Sarah fallen-version as perceived by the Lymers. Though the poem does not mention the Cobb, nor specifies where the woman is, what sea she stares, the echoes between Hardy's unnamed woman and Sarah affect one another so as to make them interchangeable.

One could therefore assume that Sarah's first appearance occurs intertextually and intermedially by means of Hardy's poem, resembling a picture/painting. However, though initially Sarah may be seen as a resonance of this 'riddle' woman, Sarah gets distanced from her when one discovers that her story had been but a deliberate invention. The Lymers's perception of Sarah is also based on an invention, whose rumors are repeated and spread. 
As such, three female characterizations derive from the dialogue Fowles produces while re-activating Austen's and Hardy's women: in Louisa, who falls on the Cobb's steps, Austen materializes a criticism of immature and inconsequential feminine behavior; significantly, in terms of plot, Louisa's accident also contributes for Wentworth to re-evaluate Anne's persuasion to have refused him years before. Louisa's fall, therefore, irradiates issues regarding (lack of) female psychological and emotional development. Hardy's woman is charming, lonely, gazing at the sea, in a typically passive Victorian attitude. Ironically, for a great part of TFLW, Sarah gets identified with her, since the Lymers believe that she 'stretches her eyes over the sea' because she is waiting for the lieutenant. But the fact is that being a metafictional novel, there is no Victorian fallen Sarah (except for the Lymers), since there was no sexual attachment with the lieutenant, nor any abandonment to regret. Fowles has parodically re-written the fallen woman; by doing so, he has given Sarah a freedom and a life of her own, attuned with the twentieth-century modern sensibility of women's subjectivity. No wonder Sarah thus embodies the sensibility of a century to come.

\section{Notes}

1. Also referred to throughout the text as TFLW.

2. Both Rajewsky (2012) and Clüver (2011) discuss the categories of intermediality as: media transposition (adaptation, novelization); media combination (opera, theatre, comics, film); and intermedia references - of which intertextuality plays a significant part.

3. See Azerêdo's "Words, Images and Invention: The Power of Metafiction in Austen, McEwan and Joe Wright", regarding the discussion on the significance of the epigraph taken from Austen's Northanger Abbey in McEwan's Atonement.

4. See Azerêdo's Jane Austen on the Screen: A Study of Irony in Emma; and Azerêdo's Para Celebrar Jane Austen: Diálogos entre Literatura e Cinema.

5. Abbreviation for video blog or video log, the vlog is a blog which has video as medium.

6. Isotopy, according to Childers and Hentzi (161-162), refers to "The repetition of an idea in a text on different levels and through different signs .... The isotopy - the deployment of synonymous terms and figures of speech throughout the description gives the text its coherence".

7. See Said's "Jane Austen and empire".

8. See Azerêdo's "From Page to Screen: Images of Englishness in Emma."

9. Information about Bosch is available at: <https://www.hieronymus-bosch.org/>.

10. We have used this sign to demarcate the chapters.

11. The narrator positions himself from the perspective of 1969 , the year when the novel was published, and not 1867, the diegetic time the characters inhabit.

\section{References}

Acheson, James, editor. John Fowles. Palgrave Macmillan, 2013.

Austen, Jane. Persuasion. 1818. Oxford University Press, 1990.

Azerêdo, Genilda. "From Page to Screen: Images of Englishness in Emma." Revista de 
Estudos Anglo-Americanos, no. 27-28, 2003-2004, pp. 81-89.

. Jane Austen on the Screen: A Study of Irony in Emma. Editora Universitária da UFPB, 2009.

"Words, Images and Invention: The Power of Metafiction in Austen, McEwan and Joe Wright." Revista de Estudos Anglo-Americanos, no. 34, 2010, pp. 6-22. Para Celebrar Jane Austen: Diálogos entre Literatura e Cinema. Appris, 2013.

Bedggood, Daniel. "John Fowles and the Writing Process." John Fowles, edited by James Acheson, Palgrave Macmillan, 2013, pp. 49-61.

Bloom, Harold. The Western Canon: The Books and Schools of the Ages. 1994. Riverhead Books, 1995.

Chatman, Seymour. Coming to Terms: The Rhetoric of Narrative in Fiction and Film. 1990. Cornell University Press, 1993.

Clüver, Claus. "Intermidialidade." Pós: Revista do Programa de Pós-Graduação em Artes da Escola de Belas Artes da UFMG, vol. 1, no. 2, 2011, pp. 8-23.

Fowles, John. The French Lieutenant's Woman. 1969. Vintage Books, 2004.

Foucault, Michel. A Ordem do Discurso. 1971. Translated by Laura Fraga de Almeida Sampaio. Edições Loyola, 1996.

Heffernan, James A. W. "Ekphrasis: Theory." Handbook of intermediality, edited by Gabriele Rippl, De Gruyter, 2015, pp. 35-49.

Hutcheon, Linda. The Politics of Postmodernism. 1989. Routledge, 1990. Narcissistic Narrative: The Metafictional Paradox. 1980. Routledge, 1991. A Theory of Parody: The Teachings of Twentieth-Century Art Forms. 1985. Illinois University Press, 2000.

Karastathi, Sylvia. "Ekphrasis and the Novel/Narrative Tradition." Handbook of Intermediality, edited by Gabriele Rippl, De Gruyter, 2015, pp. 92-112.

Louvel, Liliane. "Nuanças do Pictural." Intermidialidade e Estudos Interartes, edited by Thaïs Flores Nogueira Diniz, Editora UFMG, 2012, pp. 47-69.

Nabokov, Vladimir. Lectures on Literature. 1980. A Harvest Book, 1982.

Natoli, Joseph, and Linda Hutcheon, editors. A Postmodern Reader. State U of New York P, 1993.

Phiddian, Robert. "Are Parody and Deconstruction Secretly the Same Thing?" New Literary History, vol. 28, no. 4, 1997, pp. 673-696.

Rajewsky, Irina O. "Intermidialidade, Intertextualidade e 'Remediação': Uma Perspectiva Literária sobre a Intermidialidade." Intermidialidade e Estudos Interartes, edited by Thaïs Flores Nogueira Diniz, Editora UFMG, 2012, pp. 15-45.

Rippl, Gabriele, editor. Handbook of Intermediality. De Gruyter, 2015.

Samoyault, Tiphaine. A Intertextualidade. 2001. Translated by Sandra Nitrini. Aderaldo \& Rothchild, 2008.

Stephenson, William. Fowles's The French Lieutenant's Woman. Continuum, 2007.

"The locations of Persuasion". Persuasion: A Reading Map, https://persuasionlis763. weebly.com/persuasion-locations.html. Accessed 25 Aug. 2020.

Waugh, Patricia. Metafiction: The Theory and Practice of Self-Conscious Fiction. 1984. Routledge, 1996.

Weldon, Fay. Letters to Alice on First Reading Jane Austen. Sceptre, 1984. 
Wiltshire, John. Recreating Jane Austen. Cambridge University Press, 2001.

Woolf, Virginia. Women and Writing. Edited by Michèle Barrett. The women's press, 1988.

Recebido em: 06/07/2020

Aceito em: 13/08/2020 